\title{
Chemical

\section{Oxidative Response and Micronucleus Centromere Assay in HEp-2 Cells Exposed to Fungicide Iprodione}

\author{
Gabriela Chaufan, ${ }^{\dagger, \S}$ Camila Galvano, ${ }^{\ddagger}$ Mariela Nieves, ${ }^{\ddagger} \S$ Marta D. Mudry, ${ }^{\ddagger}$, \\ Maria del Carmen Ríos de Molina, ${ }^{\dagger, \S}$ and Nancy B. Andrioli* ${ }^{*} \neq 0$
}

\begin{abstract}
${ }^{\dagger}$ Laboratorio de Enzimología Estrés y Metabolismo, Departamento de Química Biológica, Facultad de Ciencias Exactas y Naturales, Consejo de Investigaciones Científicas y Técnicas, Universidad de Buenos Aires (IQUIBICEN-CONICET), Ciudad Universitaria, Pabellón II, $4^{\circ}$ Piso Laboratories. 43-46, C1428EGA Buenos Aires, Argentina

${ }^{\ddagger}$ GIBE (Grupo de Investigación en Biología Evolutiva), FCEyN-UBA, Facultad de Ciencias Exactas y Naturales, Instituto de Ecología, Genética y Evolución de Buenos Aires - Consejo de Investigaciones Científicas y Técnicas), Universidad de Buenos Aires (IEGEBA-CONICET), Ciudad Universitaria, Pabellón II, $4^{\circ}$ Piso Laboratories. 43-46, C1428EGA Buenos Aires, Argentina

${ }^{\S}$ Consejo Nacional de Investigaciones Cientificas y Técnicas, Universidad de Buenos Aires, C1428EGA Buenos Aires, Argentina
\end{abstract}

ABSTRACT: The fungicide agents are a key component in the fruits and vegetables production. The Iprodione residues are one of the pesticide more frequently found in food products. The available data about the cytotoxicity of iprodione and its metabolites are scarce and do not allow characterization of its genotoxic potential and define the risk assessment.The human larynx epidermoid carcinoma cell line (HEp-2) has been shown to be sensitive to the toxic effects of xenobiotics of different origin and have been often used in citotoxicity and genotoxicity studies. The purpose of this paper is to evaluate the induction of genotoxicity and the role of oxidative stress in HEp-2cell line by exposure to the IP. The MTT test for viability resulted in $\mathrm{CL}_{50} 85.86$ (77.0595.68) $\mu \mathrm{g} / \mathrm{mL}$ of Iprodione. On the basis of this result, we proceeded to expose the cells to the sublethal concentrations (below the $\mathrm{CL}_{50}$ ) during $24 \mathrm{~h}$ to analyze the mitotic index and nuclear division index in order to determine the

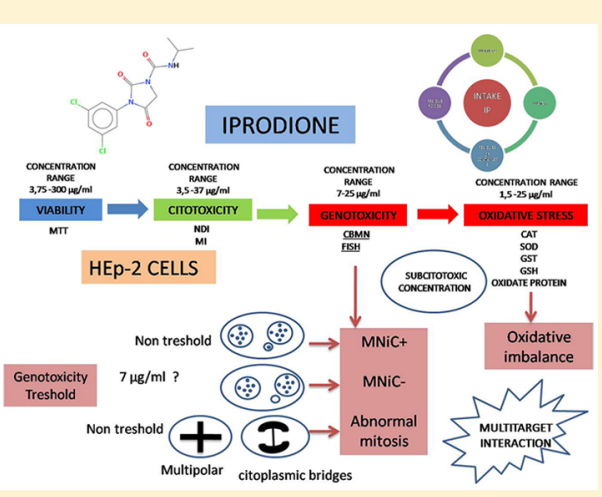
subcytotoxic concentrations of IP which the genotoxicity was evaluated. The subcytotoxic concentrations of 7,17, and $25 \mu \mathrm{g} /$ $\mathrm{mL}$ IP induced aneugenic effects as micronuclei centromere positive whereas $17 \mu \mathrm{g} / \mathrm{mL}$ was a threshold for centromere negative micronuclei induction in HEp- 2 cells. The abnormal mitosis was induced for exposition of Hep- 2 cells to the three concentrations. According to the result obtained, citotoxicity and genotoxicity oxidative stress studies were performed in 1.5 , 7.0, and $25 \mu \mathrm{g} / \mathrm{mL}$ of IP. The results showed that the GSH intracellular content, the SOD activity and the levels of oxidative damage of the proteins were affected lead to redox imbalance. The decreased in the SOD activity and protein oxidation were in according to the result obtained to genotoxicity, suggesting that different biological targets could be affected.

\section{INTRODUCTION}

The application of fungicide agents constitutes a key component in the fruits and vegetables production during seeds treatment and vegetal growth and the stage of postharvest storage and distribution. ${ }^{1}$ As a result of this practice, some potential issues can be identified, for instance, (1) the presence of fungicide residues in fresh or processed food. Most of the fungicide residues can remain stable in food, although the risk of people's consumption is related with the processing factors. ${ }^{2,3}(2)$ The contact of applicators with the fungicide agent. This contact should be reduced by applying safety measures in order to prevent the fungicide from entering the organism. ${ }^{4,5}$ (3) The environmental pollution caused during the fungicide production and application, and the containers disposal. ${ }^{6-8}$

Studies carried out by the Environmental Working Group have detected fungicide residues in food products for babies, commercialized by Gerber (Fremont, MI), Heinz (Pittsburgh, PA), and Beech-Nut (St. Louis, MO). ${ }^{9}$ Furthermore, these studies show that one of the pesticide residues more frequently found and with greater content of such substances is iprodione (IP). ${ }^{10-12}$ Studies conducted in animals proved that IP shows low acute toxicity. However, it is classified into the B2 group as "likely" carcinogenic in humans, based on evidence from the induction of liver tumors in mice of both sexes and in male rats. ${ }^{13}$ Studies in mice show that the exposure to IP induces the activity of microsomal enzymes, the proliferation of hepatocytes, and hepatomegaly. ${ }^{14,15}$ In addition, other findings show that it is an endocrine disruptor that causes reproductive abnormalities in Sprague-Dawley rats $^{16}$. Other studies indicate that dicarboximides fungicides, such as IP and vinclozolin, induce lipid peroxidation by means of the action of reactive oxygen species in funguses, but its effect over mammalian cells is not yet clearly studied or defined. ${ }^{14,17}$ The OCDE commission implemented the regulation (EU)

Received: December 15, 2018

Published: January 31, 2019 
concerning the nonrenewal of approval of the active substance iprodione in the 2017 year, because available data about the cytotoxicity of this component and its metabolites are scarce and do not allow to characterize its genotoxic potential and residues definition for risk assessment. ${ }^{18}$

It is known that genotoxicity is result of the direct interaction with the DNA or other indirect mechanisms involved interactions with non-DNA targets. Genotoxicity induces abnormalities in cells such as micronuclei (MNi), nuclear buds (NB), and nucleoplasmic bridges (NPB), observed in interphase, as result of loss and break chromosome, dicentric chromosome, and gene amplification, respectively. The cytokinesis-block micronucleus cytome assay (CBMN) allows measure the cytotoxic/cytostatic and genotoxic effects in culture human cells. Abnormalities observed in mitosis include chromosomal fragment, chromosome lagged, anaphasic/telophasic bridges and multipolar divisions. The human larynx epidermoid carcinoma cell line (HEp-2) have been shown to be sensitive to the toxic effects of xenobiotics of different origin and have been often used in citotoxicity and genotoxicity studies. ${ }^{19-24}$

In view of the foregoing, it can be concluded that there is not enough information on the literature that allows defining the IP genotoxic and oxidative potential in human cells. Therefore, the purpose of this paper is to evaluate the induction of genotoxicity and the role of oxidative stress in HEp-2 cells by exposure to the IP.

\section{MATERIALS AND METHODS}

Reagents. Iprodione, 3-(3,5-dichlorophenyl)- $\mathrm{N}$-(1-methylethyl) 2,4-dioxo-1-imidazoline-carboximide $\left(\mathrm{C}_{13} \mathrm{H}_{13} \mathrm{C}_{12} \mathrm{~N}_{3} \mathrm{O}_{3}\right)$, CAS No. 36734-19-7 was purchased from Sigma-Aldrich (CAS No. 3673419-7), modified eagle's medium (MEM), MEM vitamin solution, MEM nonessential amino acid solution, and $0.05 \%$ tripsin-EDTA, were purchased from Laboratorio Micro Vet SRL (Buenos Aires, Argentina). Fetal bovine serum (FBS) was obtained from BIO-NOS (Buenos Aires, Argentina). The 1-chloro-2,4-dinitrobenzene (CDNB) (CAS No. 97-00-7), 2,4-dinitrophenylhydrazine (DNPH) (CAS No. 119-26-6), 3-(4,5-dimethyl-thiazol-2-yl)-2,5-diphenyl-tetrazolium bromide (MTT) (CAS No. 298-93-1), 5,5-dithiobis(2-nitrobenzoic acid) (DTNB) (CAS No. 69-78-3), cytochalasin B (CAS No. 14930-96-2), glutathione (GSH) (CAS No. 70-18-8) were purchased from SigmaAldrich, Giemsa (CAS No. 51811-82-6) was purchased from Biopur S.R.L. (Riccheri 195, Rosario, Argentina), and human pancentromeric probe was purchased from Lexel S.R.L. (Luis Saenz Peña 1937, CABA, Argentina).

Cell Culture. The human cell line HEp-2 was obtained from the ABAC (Asociación Banco Argentino de Células from the Autonomous City of Buenos Aires, Argentina) and it was cultured in minimal essential medium (MEM) supplemented with $10 \%$ heat-inactivated fetal bovine serum (FBS), 100 units $/ \mathrm{ml}$ penicillin, $100 \mathrm{mg} / \mathrm{mL}$ streptomycin, and $2.5 \mu \mathrm{g} / \mathrm{mL}$ amphotericin B. Cells were cultured at $37{ }^{\circ} \mathrm{C}$ in a humidified atmosphere of $5 \% \mathrm{CO}_{2} 95 \%$ air. Cell culture medium was renewed twice a week. After 7 days, cells became confluent and ready to use. Prior to use, iprodione was first dissolved in acetone and then diluted in culture medium. The final solvent concentration was less than $1 \%$ for all treatments. Negative controls (untreated cells and solvent vehicle-treated cells) were run simultaneously with herbicide-treated cultures. None of the treatments produced significant $\mathrm{pH}$ changes in the culture medium. For all experiments, confluent attached cells were removed from cell culture dishes with $0.25 \%$ sterile trypsin and diluted with MEM/10\% FBS. For MTT assay, cells were reincubated into 96 -well plates $(0.2 \mathrm{~mL} ; 2$ $\times 10^{4}$ cells/well), and cytokinesis-block micronucleus (CBMN) assay was performed into 6 -well plates $\left(2 \mathrm{~mL} ; 3.8 \times 10^{5}\right.$ cells/well $)$. For the other experiments, cells were replated into Petri dishes $(8 \mathrm{~mL} ; 7.5 \times$ 106 cell/plates).

Viability MTT Assay. To determine the range of concentrations of IP that keep cells metabolic activity, we exposed cell cultures at iprodione range from 3.75 to $300 \mu \mathrm{g} / \mathrm{mL}$ and negative control. We used the method of Mossman ${ }^{25}$ with minor modifications. Briefly, cells were exposed for $24 \mathrm{~h}$ in serum-free medium to different dilutions of iprodione. Following incubation, treatment cell culture medium was removed; cells were washed with PBS and replaced with $1 \mathrm{mg} / \mathrm{mL}$ of sterilized MTT solution. This MTT solution was freshly prepared in MEM containing no FBS, since it has been shown that FBS can dose-dependently inhibit formazan crystals formation with a $50 \%$ decrease in these crystals when media with $5-10 \%$ FBS is used. ${ }^{26}$ The plates with added MTT solution were then placed in the $5 \% \mathrm{CO}_{2}$ incubator for $90 \mathrm{~min}$ at $37{ }^{\circ} \mathrm{C}$. MTT solution was removed and 200 $\mu \mathrm{L}$ of ethanol was added to each well to dissolve the blue formazan crystals. Optical density was measured at $570 \mathrm{~nm}$ with background subtraction at $655 \mathrm{~nm}$, in a BIO-RAD Benchmark microplate reader (BIO-RAD Laboratories, Hercules, CA). Results were expressed as percentage of control ( $100 \%$ cell metabolic activity). Each assay involved 12 wells per condition and the values correspond to the average of 4 independent studies.

Cytotoxicity and Genotoxicity - Cytokinesis-Block Micronucleus (CBMN) Assay. According to the results obtained from MTT test, the sublethal concentrations (lower to $\mathrm{CL}_{50} / 2$ ) were select for the CBMN assay performed following the method of Fenech. ${ }^{27}$ The cells were subcultured on glass coverslips in 6-well plates. Twenty-four hours after seeding, the medium was removed, and cells were treated with iprodione at $0,3.5,7,17,25$, and $37 \mu \mathrm{g} / \mathrm{mL}$ in serum-free medium for $24 \mathrm{~h}$. Then, cells were washed with PBS and incubated with medium containing cytochalasin B (final concentration $4 \mu \mathrm{g} / \mathrm{mL}$ ) for $18 \mathrm{~h}$. After these treatments, cells were washed with PBS and fixed with glacial acetic acid/methanol $(1: 3 \mathrm{v} / \mathrm{v})$ for 10 $\mathrm{min}$ at room temperature. Then cells were washed twice with PBS, stained with Giemsa $(\% 10 \mathrm{p} / \mathrm{v})$, washed again with PBS, and after that the slides were mounted. Three independent experiments were carried out.

Fluorescence in Situ Hybridization (FISH). In order to discriminate between clastogenic and aneugenic effects, fluorescence in situ hybridization technique (FISH) using pan-centromeric probe was performed (Rhodamine, red). The FISH procedure is conducted using total centromeric probes following the method of Steinberg et al. ${ }^{28}$ with minor modifications. Briefly, $0.5 \mu \mathrm{L}$ of probe are dissolved in $3 \mu \mathrm{L}$ of hybridization mixture. This hybridization mixture contains $30 \%$ formamide, $30 \%$ polyethylene glycol, $10 \% 20 \times$ SSC, $28 \% \mathrm{NaI}$, and $2 \%$ Tween. The resulting mixture is denatured at $70{ }^{\circ} \mathrm{C}$ for $7 \mathrm{~min}$ and then kept at $-20{ }^{\circ} \mathrm{C}$ for a few min (no more than 10) before hybridization. Drops of hybridization mixture containing the probe were applied to glass slides, sealed with synthetic glue, and codenatured at $71{ }^{\circ} \mathrm{C}$ for $8 \mathrm{~min}$. Hybridization is then conducted in a wet chamber at $37^{\circ} \mathrm{C}$ overnight. Posthybridization washes consist in placing the preparations in a koplin jar with $0.4 \times$ SSC $/ 0.3 \%$ Tween at $70{ }^{\circ} \mathrm{C}$ for $2 \mathrm{~min}$ and then place them in another koplin with $2 \mathrm{x}$ SSC/0.1\% Tween at room temperature for $2 \mathrm{~min}$. Slides are then counterstained with DAPI (Sigma). The DAPI solution was prepared by diluting $5 \mu \mathrm{L}$ of a DAPI stock solution $(20 \mu \mathrm{g} / \mathrm{mL}$ in ultrapure water) in $1 \mathrm{~mL}$ of antifade solution $(50 \mathrm{mg}$ p-phenylenediamine dihydrochloride, Sigma, in $5 \mathrm{~mL}$ of PBS). A $15 \mu \mathrm{L}$ drop of this mixture is then placed over the preparation and covered with a coverslip. The slides are analyzed under a fluorescence microscope. $\mathrm{MNi}$ containing chromosomes with centromere are indicated as $\mathrm{MNi}$ cent + , while $\mathrm{MNi}$ containing chromosomes fragments without centromere are indicated as MNi cent -.

Scoring of Slides and Data Analysis. The slides were examined under a Leica DMLB light microscope (1000X). One thousand cells per slide from the negative control and treated groups were examined to calculate the binucleate cells $(\mathrm{BN})$ frequency in interphase in order to estimate nuclear division index (NDI), $\mathrm{MNi}, \mathrm{NB}$, and NPB. The mitotic index (MI) and abnormal mitosis (AM) were quantified in mitosis. 
$\mathrm{NDI}=\left(M_{1}+2 M_{2}+3 M_{3}\right) / N$, where $M_{1}-M_{3}$ represent the number of cells with 1-4 nuclei and $N$ is the total number of cells scored.

$\mathrm{MNiC}+=$ number of $\mathrm{BN}$ cells with $\mathrm{MNi}$ cent $+/$ totals $\mathrm{BN}$ cells $\mathrm{MNiC}-=$ number of $\mathrm{BN}$ cells with $\mathrm{MNi}$ cent $-/$ total $\mathrm{BN}$ cells $\mathrm{NB}=$ number of nuclear buds per 1000 interphase cells.

$\mathrm{AM}=$ number of abnormal mitosis/total mitosis

$\mathrm{MI}=$ (number of mitosis $/ 1000$ cells $) \times 100$

Oxidative Stress and Antioxidative Response. Antioxidant Enzyme Activities. For enzyme activities determination (Catalase, Superoxide dismutase, and Glutathione S-transferase), cells were grown at confluence with the different treatments for $24 \mathrm{~h}$ at 3 concentrations of iprodione $(1.5,7$, and $25 \mu \mathrm{g} / \mathrm{mL})$. Determinations were carried out in $11000 \mathrm{~g}$ supernatants from cells lysates.

Catalase (CAT, EC 1.11.1.6) activity was determined by following hydrogen peroxide decomposition at $240 \mathrm{~nm}$ in a reaction mixture containing $50 \mathrm{mM}$ potassium phosphate buffer $(\mathrm{pH} 7.0)$ and $3 \mathrm{M}$ hydrogen peroxide. ${ }^{29}$ Results were expressed as percentage of control (100\% of activity).

Superoxide dismutase (SOD EC 1.15.1.1) activity was measured using a modify procedure in microplate of Beauchamp and Fridovich. ${ }^{30}$ The standard assay mixture contained enzymatic sample, $0.1 \mathrm{mM}$ EDTA, $13 \mathrm{mM}$ DL-methionine, $75 \mu \mathrm{M}$ nitro bluetetrazolium (NBT), and $2 \mu \mathrm{M}$ riboflavin, in $50 \mathrm{mM}$ phosphate buffer ( $\mathrm{pH} 7.9$ ), to a final volume of $0.3 \mathrm{~mL}$. Samples were exposed to intense cool white light for $5 \mathrm{~min}$. One SOD unit was defined as the enzyme amount necessary to inhibit 50\% the reaction rate. Results were expressed as percentage of control.

Glutathione S-transferase (GST, EC1.11.1.9) activity was measured by Habig et al. ${ }^{31}$ technique. Briefly, standard assay mixture in $100 \mathrm{mM}$ phosphate buffer ( $\mathrm{pH}$ 6.5) contained enzymatic sample, $100 \mathrm{mM}$ GSH solution, and $100 \mathrm{mM} 1$ chloro-2,4 dinitrobenzene (CDNB) in ethanol to a final volume of $0.8 \mathrm{~mL}$. After adding CDNB, change in absorbance at $340 \mathrm{~nm}$ was followed for $180 \mathrm{~s}$. One GST unit was defined as the amount of enzyme that catalyzes the formation of 1 $\mu$ mol of GS-DNB per minute at $25{ }^{\circ} \mathrm{C}$; results were expressed as percentage of control.

GSH Equivalents Content. GSH levels were measured in HEp-2 cells following the Anderson ${ }^{32}$ procedure with some modifications. Briefly, after being incubated into Petri dishes at early confluence (80-90\% confluent) at 3 concentrations of iprodione (1.5, 7, and 25 $\mu \mathrm{g} / \mathrm{mL})$, cells were collected, washed, and resuspended in PBS. Then, cells were lysed as described before. For the GSH determination, we proceeded as Coalova et al. ${ }^{33}$ Results were expressed as percentage of control.

Oxidative Damage. Protein oxidation was quantified as carbonyl groups according to Reznick and Packer. ${ }^{34}$ Carbonyl content was calculated from the peak absorbance (355-390 nm) using an extinction coefficient of $22000 \mathrm{M}^{-1} \mathrm{~cm}^{-1}$. Results were expressed as nmol carbonyl per mg protein. Results were expressed as percentage of control.

Statistical Analyses. The $\mathrm{LC}_{50}$ value to MTT was estimated by nonlinear regression sigmoidal dose-response method. For oxidative stress and citotoxicity parameters, statistical analyses were performed using one-way analysis of variance (ANOVA) followed by Dunnet's test using significant levels of $p<0.05$. Normality and homogeneity of variances were tested with Lilliefors and Barlett test; respectively, Graph Pad Prism 6 software was used for statistical analyses.

To study the factors that affect the abnormal genotoxicity biomarkers such as $\mathrm{MNi}$ and $\mathrm{AM}$, generalized analysis linear mixed models (GLMMs) was performed. The explanatory variables used were treatment, NDI, and IM. For $\mathrm{MNi}$ and $\mathrm{AM}$, binomial distribution was assumed. For binomial distribution, also samples were included as random factors to control overdispersion. ${ }^{35}$ The models were ranked according to their Akaike Information Criteria (AIC), the lower AIC selected as the definite model. The R 3.4.3 software was applied ${ }^{36}$ using the glmer function of the lme4 Rpackage $^{37}$ for binomial distribution. To analyze the difference in the treatment, Tukey test from the multitukey pakage was performed to the genotoxic response comparing all the pair of samples.

\section{RESULTS}

The MTT test resulted in $\mathrm{CL}_{50} 85.86(77.05-95.68) \mu \mathrm{g} / \mathrm{mL}$ of iprodione (Figure 1). On the basis of this result, we

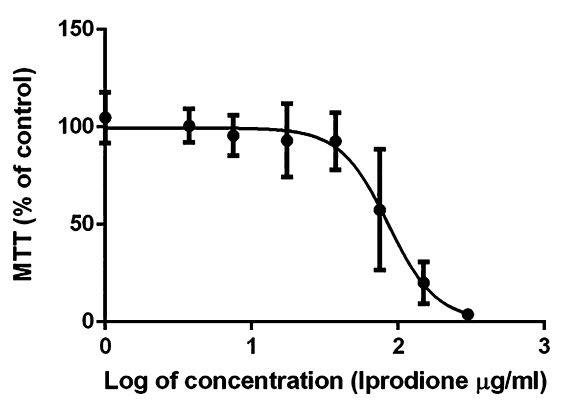

Figure 1. Dose-response curve for iprodione effects fitted by nonlinear regression. These effects were evaluated by the MTT test. Data are expressed as mean $+\mathrm{SD}(n=36)$, relative to control cells (100\% viability). MTT, 3-(4,5-dimethyl-hiazol-2-yl)-2,5-diphenyltetrazolium bromide; SD, standard deviation.

proceeded to expose the cells to the sublethal concentrations (below the $\mathrm{CL}_{50}$ ) during $24 \mathrm{~h}$ to analyze the citotoxicity as $\mathrm{MI}$ and NDI in order to determine the subcytotoxic concentrations of IP to evaluate genotoxicity. The concentrations chosen were 7,17 , and $25 \mu \mathrm{g} / \mathrm{mL}$ of IP, because the MI and NDI values do not have significant differences regarding the negative control (Figure 2A,B). The results obtained in CBMN test showed $\mathrm{MN}$ induction which included both $\mathrm{MNC}+$ as MNC-, with remarkable differences between them (Figure $3 A-D)$. The GLMMs analysis performed to evaluate genotoxicity indicated that the frequency of $\mathrm{MNi}$ are associated with the treatments, the NDI, and MI factors. When the models were performed separately, the $\mathrm{MNiC}-$ was associated significantly with the treatments and MI factors, whereas $\mathrm{MNiC}+$ was associated with the treatments, NDI, and MI factors. The most suitable model was based in the ranking according to their Akaike Information Criteria (AIC) where the best-reduced model was the model having the lower AIC.

The multiple comparisons of means to $\mathrm{MNiC}$ - throw results significant for $17 \mu \mathrm{g} / \mathrm{mL}$ and $25 \mu \mathrm{g} / \mathrm{mL}$. IP showed significant differences with respect to the negative control, whereas the values of $\mathrm{MNiC}+$ were statistically different to the negative control in all the treatments (Table 1).

In mitosis, the abnormalities found were the bridges in anaphase and multipolar division (Figure 4A,B) in the more suitable models, only the treatment factor was associated with the AM. The Tukey contrasts showed significant differences in all concentrations of IP respect to the negative control and for $7-25 \mu \mathrm{g} / \mathrm{mL}$ IP range (Table 2).

According to the result obtained to citotoxicity and genotoxicity oxidative stress, studies were performed in 1.5 , 7.0 , and $25 \mu \mathrm{g} / \mathrm{mL}$ of IP. The results showed that at 1.5 and 25 $\mu \mathrm{g} / \mathrm{mL}$ of IP the GSH intracellular content was lower with respect to control (Figure 5A). Furthermore, SOD activity is significantly lower in the cells exposed to $25 \mu \mathrm{g} / \mathrm{mL}$ of IP than those in controls, while at that same concentration the cells have a significant increase in the levels of oxidative damage of the proteins, measured as the content of carbonyl groups. (Figure 5B,E). Neither CAT nor GST showed significant differences in the concentrations tested with respect to the control (Figure 5C,D). 

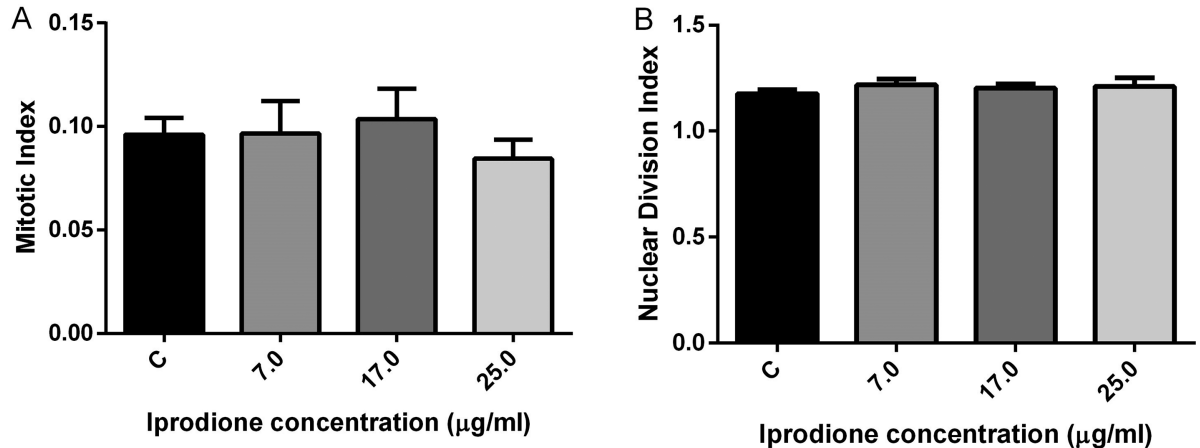

Figure 2. Cytotoxic/cytostatic effects of iprodione based on (A) nuclear division index, (B) nuclear replication index for HEp-2 cells. Results were expressed as mean $\pm \mathrm{SD}(n=9)$.
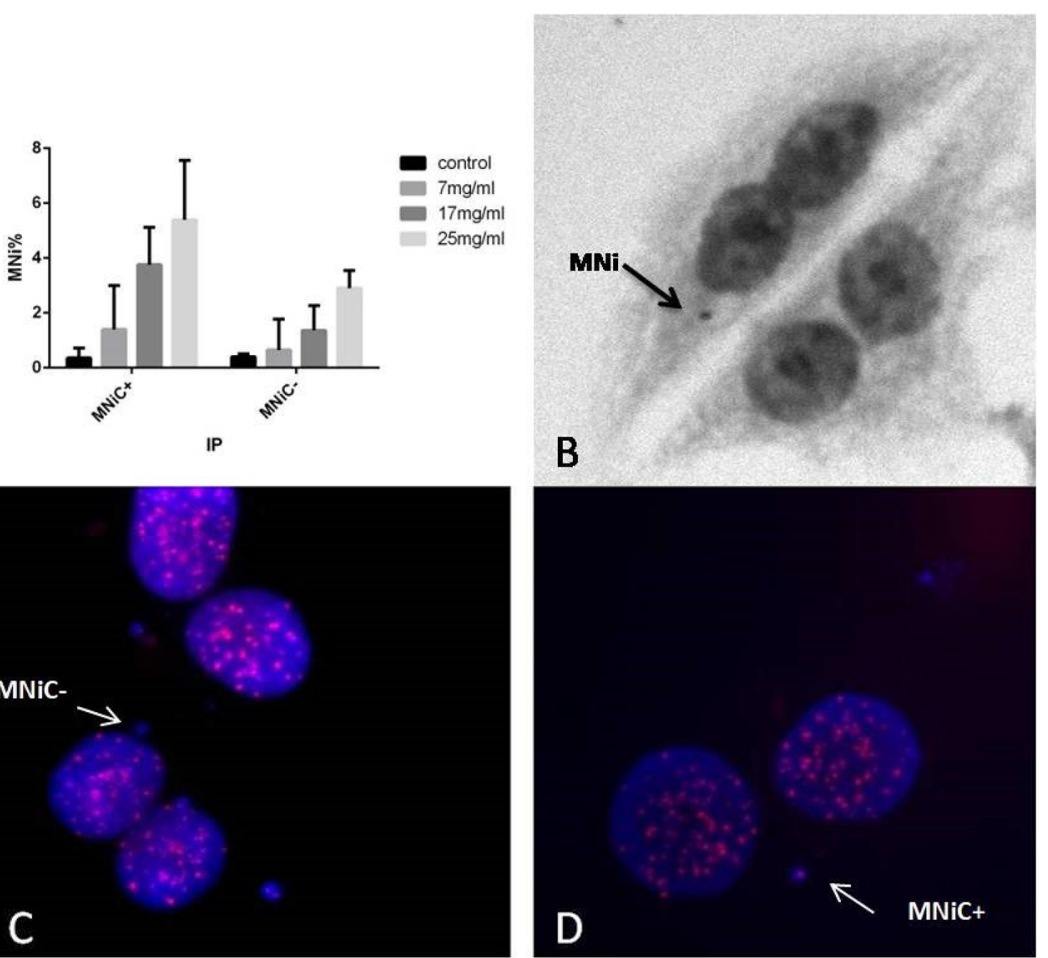

Figure 3. CBMN assay performed in HEp-2 cell line showing (A) MNi containing whole chromosomes are centromere positive $(\mathrm{MNiC}+)$ and detected by pan-centromeric probes, while $\mathrm{MNi}$ containing chromosome fragments are centromere negative (MNiC-). (B) Nuclear morphology of genotoxic effect of iprodione in HEp-2 cell line. Nuclear DNA was stained with giemsa dye and visualized by optic microscopy. Genotoxic effects were observed in interphase of cells as (C) binucleated cells with MNi cent-stained with DAPI and labeled with pan-centromeric probe respectively, and (D) binucleated cells with MNi cent+stained with DAPI and labeled with pan-centromeric probe, respectively. Nuclear DNA was stained with DAPI dye and visualized by fluorescence microscopy using filters for DAPI (blue) and for pan-centromeric probe (red).

Table 1. Multiple Comparisons of Means to $\mathrm{MNiC}-$ and $\mathrm{MNiC}+{\text { (Tukey Contrasts })^{a}}$

$\begin{array}{ccc}\text { treatment } \mu \mathrm{g} / \mathrm{mL} & p \text { values } \mathrm{MNiC}- & p \text { values } \mathrm{MniC}+ \\ 7-0 & 0.12690 & 0.00598^{* *} \\ 17-0 & 0.02695^{*} & <0.001 * * * \\ 25-0 & <0.001 * * * & <0.001 * * *\end{array}$

${ }^{a}$ Signif. codes: $* * *, 0.001 ; * *, 0.01 ; * 0.05$.

\section{DISCUSSION}

The biological systems respond to the exposure to xenobiotics by modifying their cellular and molecular status, and this can be detected by means of biomarkers. Biomarkers, such as MTT, MI, and NDI are indicators of the cell activity, thus the values that are significantly lower than control indicates cytotoxic effects. The oxidative stress and genotoxicity tests are implemented to lower concentrations than the cytotoxic ones in which the metabolic or mitotic activity allows to reveal the effect we intend to characterize for the induction the respective biomarkers. $^{38}$ Therefore, the subcitotoxic concentrations chosen to performed genotoxicity analysis were in a range containing 7, 17, and $25 \mu \mathrm{g} / \mathrm{mL}$ IP. The more suitable GLMMs used to explain the genotoxicity biomarkers induction showed the association of $\mathrm{MNiC}+$ and $\mathrm{MNC}-$ values with all the IP concentrations and MI. The $\mathrm{MNiC}+$ was also associated with the NDI. Considering that $\mathrm{MNi}$ are formed by chromosomes or chromatin fragments produced in previous mitosis and they are quantifiedin the binucleated cells, the MI and NDI variations can influence the MNi induction since they 

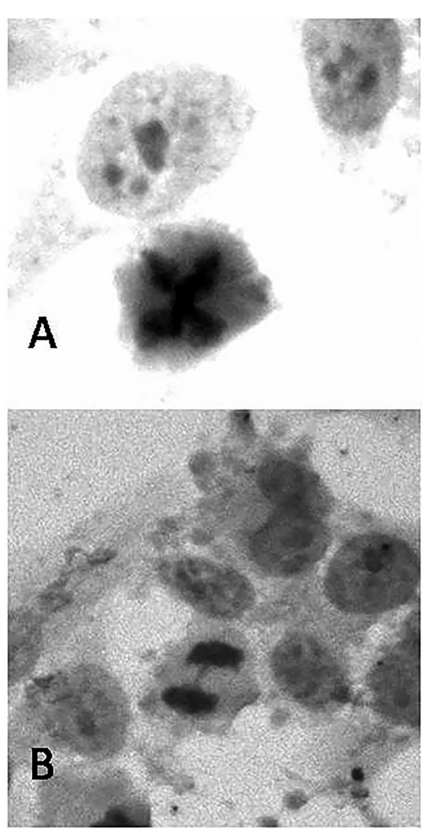

Figure 4. Abnormal mitosis. (A) Multipolarmitosis and (B) nucleoplasmic bridges.

Table 2. Multiple Comparisons of Means to AM (Tukey Contrasts) ${ }^{a}$

$\begin{array}{cc}\text { treatment } \mu \mathrm{g} / \mathrm{mL} & p \text { values AM } \\ 7-0 & <0.001^{* * *} \\ 17-0 & <0.001^{* * *} \\ 25-0 & <0.001^{* * *}\end{array}$

${ }^{a}$ Signif. codes: $* * *, 0.001 ; * *, 0.01 ; *, 0.05$.

are a measure of proliferation cells. The $\mathrm{MNiC}+$ were more induced than the $\mathrm{MNiC}-$ for all the concentrations (Table 1).

The use of a centromeric probe can fail if the chromosome attaches to the spindle but does not fail if these chromosomes are whole or broken. In order to know if the chromosome is whole, a combination of telomeric and centromeric probes could be used. In this work, we assume this limitation is due to both effects, clastogenic and aneugenic, allowing the general characterization of the damage, whereas the analysis is of the mode of action (MOA) or prediction studies in which the threshold values are required and this is not the goal.

According to more suitable GLMMs, the AM induction is associated with the treatments only and the values of IM and NDI did not show association with AM as it is expected for noncytotoxic concentrations. The genotoxicity evidenced as AM is attributed to the three concentrations of IP in the range studied, according to the Tukey contrasts analysis. The IP exposition induces disturbances on mitotic machinery evidenced as $\mathrm{MNiC}+$ and multipolar division, whereas the clastogenic effect is evidenced as $\mathrm{MNiC}-$ and anaphasic bridges. The formation of multipolar spindle is compatible with the microtubule interaction or microtubule associated proteins, ${ }^{39}$ while the bridge's induction arises from the rupture of the telomeric region which generates sticky ends. ${ }^{40}$. Both effects could be related due to genomic instability produced for interaction with several targets, involving mechanism of indirect genotoxicity. ${ }^{41}$ Indirect genotoxicity includes mechanism of oxidative damage, affecting proteins and other biomolecules including DNA. According to this hypothesis, the parameters related to oxidative stress and damage indicate that the exposure of HEp-2 cells to IP produces an effect in the redox balance and damages the proteins as consequence of exposition to IP. This imbalance is evidenced by the changes in the GSH intracellular content, the low SOD activity and the increase in the levels of oxidative damage of proteins, at the maximum tested concentration of IP. Such effects could be related to the identified genotoxic alterations for the same range of concentrations. In addition, $1.5 \mu \mathrm{g} / \mathrm{mL}$ IP concentration was included in the oxidative stress studies to analyze the behavior of this mechanism at low doses, where the response (GSH consumption together with the GST and SOD activity) is compatible with the oxidative protection. Exposure to higher concentrations would lead to the fall of SOD activity and protein oxidation according to the result obtained. The quantities and quality of the biological target and the interactions could explain the different threshold observed to clastogenic and aneugenic genotoxic effects. ${ }^{42}$

The few research studies that analyze the IP genotoxicity in the literature present controversial results. Some studies carried out using Crepis capillaries show that the IP induces lagging chromosomes and this effect is compatible with the abnormal formation of mitotic spindles. ${ }^{43}$ By contrast, the $\mathrm{MNi}$ test in Tradescantia pollen tetrads showed negative results. ${ }^{44}$ The literature about IP genotoxicity in human cells is limited to the study of the biomarkers induced by occupational or environmental exposure to pesticide mixtures which include the IP. ${ }^{45-48}$

Among the study models conducted to know about the different toxic effects of xenobiotics, the guidelines of the Organization for Economic Coordination and Development, OECD $473,{ }^{49}$ recommend the human cell lines for the chromosome aberrations' analysis as a resource that allows one to study such responses at a cellular level and identify mechanistic aspects related to the molecular interaction. ${ }^{50,51}$ Thus, the results obtained using human cells in vitro are complemented with studies performed in vivo in mammals, to obtain conclusions about the risk of human exposure. The HEp-2 is a model used in several studies to evaluate the citotoxicity and genotoxicity of xenobiotics, in which it is proved that such test system is feasible and sensitive for that purpose. ${ }^{52-56,56}$ The final acceptance of the $\mathrm{MNi}$ in vitro test for the (OECD) guideline No. $487^{57}$ places the test for the determination of the genotoxicity potential in the exploratory research, as well as in the regulatory environment. In this context, our results provide valuable and relevant information with data about IP that can be considered for the toxicological risk evaluation due to human exposure and search of genotoxicity threshold values. ${ }^{58}$ The present work carried out in a human in vitro model is the beginning of a series of studies necessary for the characterization of genotoxic agents prior to in vivo tests in experimental animals which should be avoided as long as possible in according to regulatory genotoxicology. More studies should be focused in finding the threshold to genotoxicity in vivo of IP in order to determine the concentration of residues that is compatible with food safety.

\section{AUTHOR INFORMATION}

\section{Corresponding Author}

*E-mail: nancyandrioli@gmail.com.

ORCID 8

Nancy B. Andrioli: 0000-0003-3424-0515 


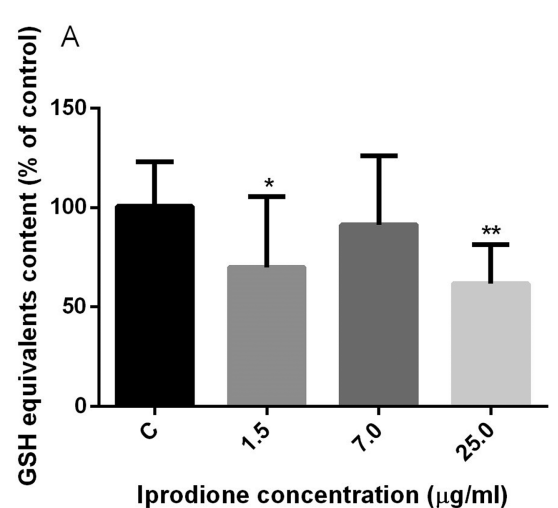

Iprodione concentration $(\mu \mathrm{g} / \mathrm{ml})$
B

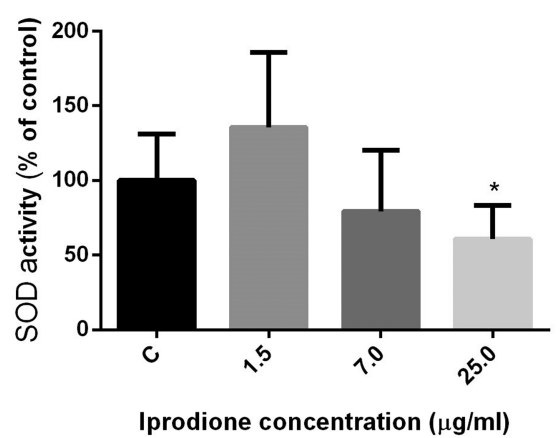

C

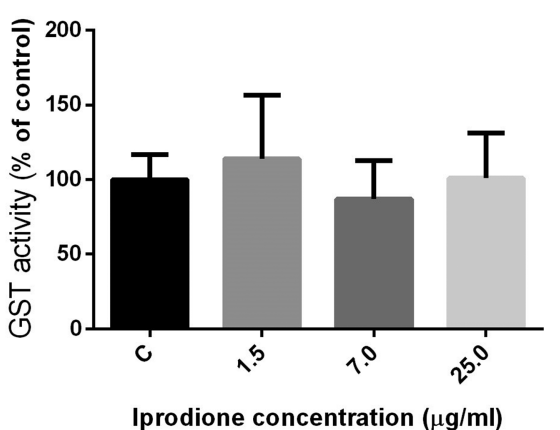

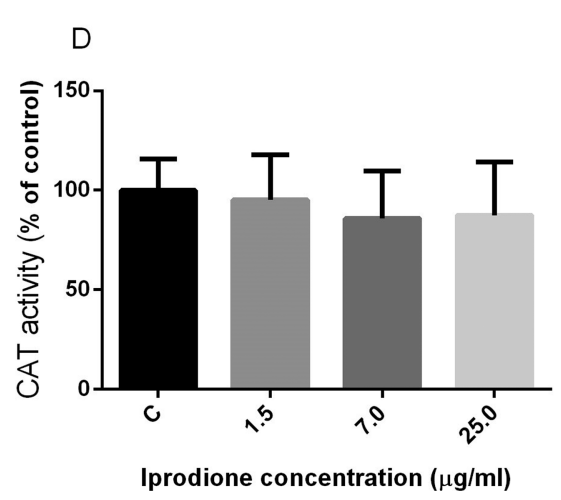

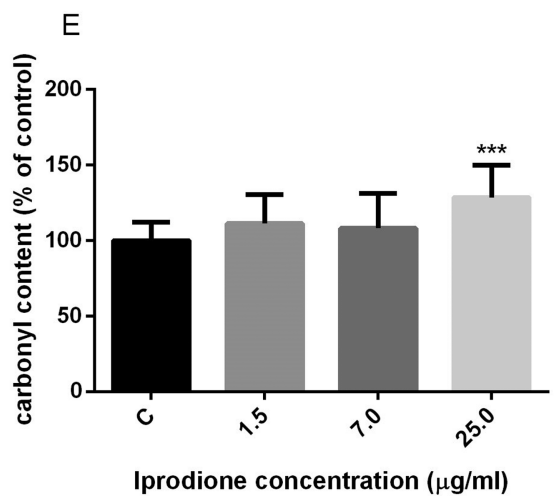

Figure 5. Enzymatic and non enzymatic antioxidant, detoxification capacity, and levels of oxidative damage of iprodione in HEp-2 cells. (A) GSH intracellular levels, (B) superoxide dismutase activity (U SOD mg ${ }^{-1}$ proteins), (C) gluthatione S-transferase activity (GST mg $\mathrm{m}^{-1}$ proteins), (D) catalase activity (CAT mg ${ }^{-1}$ proteins), and (E) carbonyl content (nmol mg ${ }^{-1}$ proteins) in $\mathrm{HEp}-2$ cells at $1.5,7.0$, and $25.0 \mu \mathrm{g} / \mathrm{mL}$ of iprodione. Results are expressed as mean \pm SD of four independent experiments $(n=16)$. Significant differences between control and treatments are indicated by asterisks: $*$ indicate $p<0.05$.

\section{Funding}

This work was supported by grants from CONICET-Argentina (Consejo Nacional de Investigaciones Científicas y Técnicas, PIP 11220130100020CO, and PIP 11220150100835CO) and from Universidad de Buenos Aires, Argentina (UBACyT 01/ Q882, and 2002013010031).

\section{Notes}

The authors declare no competing financial interest.

\section{REFERENCES}

(1) McConnell, S., Wightwick, A., Smith, T., and Porteous, C. (2003). Code of environmental best practice for viticultureSunraysia region, Environmental best practices. Department of Primary Industries, Melbourne.

(2) Zhu, X., Jia, C., Duan, L., Zhang, W., Yu, P., He, M., Zhao, E., et al. (2016) Residue behavior and dietary intake risk assessment of three fungicides in tomatoes (Lycopersicon esculentum Mill.) under greenhouse conditions. Regul. Toxicol. Pharmacol. 81, 284-287.

(3) Cantor, K. P., Blair, A., Everett, G., Gibson, R., Burmeister, L. F., Brown, L. M., and Dick, F. R. (1992) Pesticides and other agricultural risk factors for non-Hodgkin's lymphoma among men in Iowa and Minnesota. Cancer research 52 (9), 2447-2455.

(4) Butinof, M., Fernández, R., Lantieri, M. J., Stimolo, M. I., Blanco, M., Machado, A. L., and Sastre, A. (2014). Pesticides and agricultural work environments in Argentina. In Pesticides-Toxic Aspects. InTech, London.

(5) Franchini, G., Butinof, M., Blanco, M. P., Machado, A. L., Fernandez, R. A., and Díaz, M. D. P. (2016) Occupational risks associated with the use of pesticides in the green belt of Córdoba, Argentina. Acta toxicologica argentina 24 (1), 58-67.
(6) Wightwick, A., and Allinson, G. (2007) Pesticide residues in Victorian waterways: a review. Australasian Journal of Ecotoxicology 13 (3), 91-112.

(7) Komárek, M., Čadková, E., Chrastný, V., Bordas, F., and Bollinger, J. C. (2010) Contamination of vineyard soils with fungicides: a review of environmental and toxicological aspects. Environ. Int. 36 (1), 138-151.

(8) Karas, P., Metsoviti, A., Zisis, V., Ehaliotis, C., Omirou, M., Papadopoulou, E. S., Karpouzas, D. G., et al. (2015) Dissipation, metabolism and sorption of pesticides used in fruit-packaging plants: towards an optimized depuration of their pesticide-contaminated agro-industrial effluents. Sci. Total Environ. 530-531, 129-139.

(9) EWG: 1995. http://www.ewg.org/research/pesticides-babyfood. Date of access: December 2016.

(10) U.S. Department of Agriculture, Agricultural Marketing Service, 2014. Science and Technology. Pesticide Data Program. Available at. https: / / www.ams.usda.gov/sites/default/files / media / 2013\%20PDP\%20Anuual\%20Summary.pdf. Date of access: March 2017.

(11) Wang, S., Xu, Y., Pan, C., Jiang, S., and Liu, F. (2007) Application of matrix solid-phase dispersion and liquid chromatography-mass spectrometry to fungicide residue analysis in fruits and vegetables. Anal. Bioanal. Chem. 387 (2), 673-685.

(12) Zhang, M., Wang, W., Zhang, Y., Teng, Y., and Xu, Z. (2017) Effects of fungicide iprodione and nitrification inhibitor 3, 4dimethylpyrazole phosphate on soil enzyme and bacterial properties. Sci. Total Environ. 599, 254-263.

(13) U.S. EPA. Environmental Protection Agency: Re-registration Eligibility Decision (RED), Iprodione. (1998). EPA,Washington, D.C.

(14) Radice, S., Marabini, L., Gervasoni, M., Ferraris, M., and Chiesara, E. (1998) Adaptation to oxidative stress: effects of 
vinclozolin and iprodione on the HepG2 cell line. Toxicology 129 (23), 183-191.

(15) Radice, S., Ferraris, M., Marabini, L., Grande, S., and Chiesara, E. (2001) Effect of iprodione, a dicarboximide fungicide, on primary cultured rainbow trout (Oncorhynchus mykiss) hepatocytes. Aquat. Toxicol. 54 (1-2), 51-58.

(16) Washington, T., and Tchounwou, P. B. (2004) Cytotoxicity and transcriptional activation of stress genes in human liver carcinoma (HepG2) cells exposed to iprodione. Int. J. Environ. Res. Public Health 1 (1), 12-20.

(17) Prutner, W., Nicken, P., Haunhorst, E., Hamscher, G., and Steinberg, P. (2013) Effects of single pesticides and binary pesticide mixtures on estrone production in H295R cells. Arch. Toxicol. 87 (12), 2201-2214.

(18) https://eur-lex.europa.eu/eli/reg_impl/2017/2091/oj, accessed 12/01/2018.

(19) Stammati, A., Nebbia, C., De Angelis, I., Albo, A. G., Carletti, M., Rebecchi, C., Dacasto, M., et al. (2005) Effects of malachite green (MG) and its major metabolite, leucomalachite green (LMG), in two human cell lines. Toxicol. In Vitro 19 (7), 853-858.

(20) De Angelis, I., Hoogenboom, L. A. P., Huveneers-Oorsprong, M. B. M., Zucco, F., and Stammati, A. (1994) Established cell lines for safety assessment of food contaminants: differing furazolidone toxicity to V 79, HEp-2 and Caco-2 cells. Food Chem. Toxicol. 32 (5), 481488.

(21) Osman, I. F., Baumgartner, A., Cemeli, E., Fletcher, J. N., and Anderson, D. (2010) Genotoxicity and cytotoxicity of zinc oxide and titanium dioxide in HEp-2 cells. Nanomedicine 5 (8), 1193-1203.

(22) Bianchi, E., Lessing, G., Brina, K. R., Angeli, L., Andriguetti, N. B., Peruzzo, J. R. S., da Silva, L. B., et al. (2017) Monitoring the genotoxic and cytotoxic potential and the presence of pesticides and hydrocarbons in water of the Sinos River basin, southern Brazil. Arch. Environ. Contam. Toxicol. 72 (3), 321-334.

(23) Andrioli, N. B., Chaufan, G., Coalova, I., Ríos de Molina, M. C., and Mudry, M. D. (2017) HEp-2 como modelo experimental para evaluar los efectos genotóxicos del arsénico inorgánico pentavalente. BAG. Journal of basic and applied genetics 28 (2), 15-24.

(24) Chaufan, G., Coalova, I., and Molina, M. D. C. R. D. (2014) Glyphosate commercial formulation causes cytotoxicity, oxidative effects, and apoptosis on human cells: differences with its active ingredient. Int. J. Toxicol. 33 (1), 29-38.

(25) Mosmann, T. (1983) Rapid colorimetric assay for cellular growth and survival: application to proliferation and cytotoxicity assays. J. Immunol. Methods 65 (1-2), 55-63.

(26) Talorete, T. P., Bouaziz, M., Sayadi, S., and Isoda, H. (2007) Influence of medium type and serum on MTT reduction by flavonoids in the absence of cells. Cytotechnology 52 (3), 189-198.

(27) Fenech, M. (2000) The in vitro micronucleus technique. Mutat. Res., Fundam. Mol. Mech. Mutagen. 455 (1-2), 81-95.

(28) Steinberg, E. R., Nieves, M., Fantini, L., and Mudry, M. D. (2014) Primates karyological diagnosis and management programs applications. J. Med. Primatol. 43 (6), 455-467.

(29) Aebi, H. (1984) Catalase in vitro. In Methods in enzymology, Vol. 105, pp 121-126, Academic Press, New York.

(30) Beauchamp, C., and Fridovich, I. (1971) Superoxide dismutase: improved assays and an assay applicable to acrylamide gels. Anal. Biochem. 44 (1), 276-287.

(31) Habig, W. H., Pabst, M. J., and Jakoby, W. B. (1976) Glutathione S-transferase AA from rat liver. Arch. Biochem. Biophys. 175 (2), 710-716.

(32) Anderson, M. E. (1985) Determination of glutathione and glutathione disulfide in biological samples. In Methods in enzymology, Vol. 113, pp 548-555, Academic Press, New York.

(33) Coalova, I., de Molina, M. D. C. R., and Chaufan, G. (2014) Influence of the spray adjuvant on the toxicity effects of a glyphosate formulation. Toxicol. In Vitro 28 (7), 1306-1311.

(34) Reznick, A. Z., and Packer, L. (1994) Oxidative damage to proteins: spectrophotometric method for carbonyl assay. In Methods in enzymology, Vol. 233, pp 357-363, Academic Press, New York.
(35) Harrison, X. A. (2015) A comparison of observation-level random effect and Beta-Binomial models for modelling overdispersion in Binomial data in ecology and evolution. PeerJ 3, No. el114.

(36) R Core Team, R. A Language and environment for statistical computing. Vienna, Austria, 2017.

(37) Bates, D., Mächler, M., Bolker, B., and Walker, S. (2014). Fitting linear mixed-effects models using lme4. arXiv preprint arXiv: 1406.5823 , accessed 12/01/2018.

(38) Gebel, T. W. (2001) Genotoxicity of arsenical compounds. Int. J. Hyg. Environ. Health 203 (3), 249-262.

(39) Andrioli, N. B., Soloneski, S., Larramendy, M. L., and Mudry, M. D. (2014) Induction of microtubule damage in Allium cepa meristematic cells by pharmaceutical formulations of thiabendazole and griseofulvin. Mutat. Res., Genet. Toxicol. Environ. Mutagen. 772, 15 .

(40) Maciejowski, J., Li, Y., Bosco, N., Campbell, P. J., and de Lange, T. (2015) Chromothripsis and kataegis induced by telomere crisis. Cell 163 (7), 1641-1654.

(41) Fenech, M., Knasmueller, S., Bolognesi, C., Bonassi, S., Holland, N., Migliore, L., Kirsch-Volders, M., et al. (2016) Molecular mechanisms by which in vivo exposure to exogenous chemical genotoxic agents can lead to micronucleus formation in lymphocytes in vivo and ex vivo in humans. Mutat. Res., Rev. Mutat. Res. 770, 1225.

(42) Kirsch-Volders, M., Vanhauwaert, A., Eichenlaub-Ritter, U., and Decordier, I. (2003) Indirect mechanisms of genotoxicity. Toxicol. Lett. 140, 63-74.

(43) Gadeva, P., and Dimitrov, B. (2008) Genotoxic effects of the pesticides Rubigan, Omite and Rovral in root-meristem cells of Crepis capillaris L. Mutat. Res., Genet. Toxicol. Environ. Mutagen. 652 (2), 191-197.

(44) Fadic, X., Placencia, F., Domínguez, A. M., and Cereceda-Balic, F. (2017) Tradescantia as a biomonitor for pesticide genotoxicity evaluation of iprodione, carbaryl, dimethoate and 4, 4'-DDE. Sci. Total Environ. 575, 146-151.

(45) Bolognesi, C. (2003) Genotoxicity of pesticides: a review of human biomonitoring studies. Mutat. Res., Rev. Mutat. Res. 543 (3), 251-272.

(46) Graillot, V., Takakura, N., Hegarat, L. L., Fessard, V., Audebert, M., and Cravedi, J. P. (2012) Genotoxicity of pesticide mixtures present in the diet of the French population. Environmental and molecular mutagenesis 53 (3), 173-184.

(47) Wilhelm, C. M., Calsing, A. K., and Da Silva, L. B. (2015) Assessment of DNA damage in floriculturists in southern Brazil. Environ. Sci. Pollut. Res. 22 (11), 8182-8189.

(48) Rizzati, V., Briand, O., Guillou, H., and Gamet-Payrastre, L. (2016) Effects of pesticide mixtures in human and animal models: an update of the recent literature. Chem.-Biol. Interact. 254, 231-246.

(49) OCDE (2016), Test No. 473: In Vitro Mammalian Chromosomal Aberration Test, OECD Guidelines for the Testing of Chemicals, Section 4, Éditions OCDE, Paris, http://sci-hub.tw/10. 1787/9789264264649-en. Date of access: March 2017.

(50) Westerink, W. M., Schirris, T. J., Horbach, G. J., and Schoonen, W. G. (2011) Development and validation of a high-content screening in vitro micronucleus assay in CHO-k1 and HepG2 cells. Mutat. Res., Genet. Toxicol. Environ. Mutagen. 724 (1), 7-21.

(51) Wilkening, S., Stahl, F., and Bader, A. (2003) Comparison of primary human hepatocytes and hepatoma cell line Hepg2 with regard to their biotransformation properties. Drug metabolism and disposition 31 (8), 1035-1042.

(52) Andrighetti-Fröhner, C. R., Kratz, J. M., Antonio, R. V., Creczynski-Pasa, T. B., Barardi, C. R., and Simões, C. M. (2006) In vitro testing for genotoxicity of violacein assessed by Comet and Micronucleus assays. Mutat. Res., Genet. Toxicol. Environ. Mutagen. 603 (1), 97-103.

(53) Rizo, W. F., Ferreira, L. E., Colnaghi, V., Martins, J. S., Franchi, L. P., Takahashi, C. S., Fachin, A. L., et al. (2013) Cytotoxicity and genotoxicity of coronaridine from Tabernaemontana catharinensis $\mathrm{A}$. 
DC in a human laryngeal epithelial carcinoma cell line (Hep-2). Genet. Mol. Biol. 36 (1), 105-110.

(54) IGomaa, I. E., Bhatt, S., Liehr, T., Bakr, M., and El-Tayeb, T. A. (2015) A study on biological application of ag and co/ag nanoparticles cytotoxicity and genotoxicity. Nanomaterials and Nanotechnology for Composites: Design, Simulation and Applications, 139.

(55) dos Santos Branco, C., de Lima, É. D., Rodrigues, T. S., Scheffel, T. B., Scola, G., Laurino, C. C. F. C., Salvador, M., et al. (2015) Mitochondria and redox homoeostasis as chemotherapeutic targets of Araucaria angustifolia (Bert.) O. Kuntze in human larynx HEp-2 cancer cells. Chem.-Biol. Interact. 231, 108-118.

(56) Ahamed, M., Alhadlaq, H. A., Ahmad, J., Siddiqui, M. A., Khan, S. T., Musarrat, J., and Al-Khedhairy, A. A. (2015) Comparative cytotoxicity of dolomite nanoparticles in human larynx HEp2 and liver HepG2 cells. J. Appl. Toxicol. 35 (6), 640-650.

(57) OECD (2014), Test No. 487: In Vitro Mammalian Cell Micronucleus Test; OECD Publishing, Paris, http://sci-hub.tw/10. 1787/9789264224438-en. Date of access: March 2017.

(58) Kirkland, D. J., and Müller, L. (2000) Interpretation of the biological relevance of genotoxicity test results: the importance of thresholds. Mutat. Res., Genet. Toxicol. Environ. Mutagen. 464 (1), 137-147. 